- Research Note -

\title{
Effect of Restricted Time of Access to Grass \\ Silage on Voluntary Intake of Lactating \\ Dairy Cows Housed in Free Stall Barn
}

\author{
Hiroshi Sato, Yoshio Kudo and Tetsuo Mishima \\ Hokkaido National Agricultural Experiment Station, \\ Sapporo-shi 061-01
}

(Received April 18, 1985)

Key words: time access and DM intake, voluntary intake of cow, DM intake in free stall, silage intake of dairy cow, eating of silage

Voluntary intake of forage by dairy cows is regulated predominantly by rumen capacity, fill during a meal and the passage rate of digesta. On general grounds concerning these factors, forage intake might be markedly influenced by the time of access to the diet. The response of forage intake to time restriction of access, how ever, is not well documented in a loose housing system based upon self-feeding of grass silage. The present experiment was carried out to examine the effect of restricted time on silage intake in lactating cows housed in a free stall barn.

\section{Materials and Methods}

Twelve lactating Holstein-Friesian cows (mean live weight $626 \mathrm{~kg} ; 10$ in mid or late lactation, 2 in early lactation) were used in a $4 \times 4$ Latin square design to examine the effect of $2,5,10 \mathrm{hr}$ and free access to a grass silage (moisture $72 \%, \mathrm{CP}$ 9. $4 \%$ and $\mathrm{C}$. Fiber $34.2 \%$ on DM basis, $\mathrm{pH} \mathrm{4.3)}$ on voluntary intake of the silage. They were housed in a free stall barn. The silage was given at $10 \mathrm{AM}$ in individual troughs equipped with an electronic door which enabled an intake estimation for each cow, and the remainder was taken away from the troughs at $8 \mathrm{AM}$ the next day. No feed was available during milking in the parlour. Consequently, in free access, the silage was available for $21-21.5 \mathrm{hr}$ daily.

After evening milking, $4-5 \mathrm{~kg}$ of Orchardgrass hay (CP $11.5 \%$, C. Fiber $32.5 \%$ on DM basis) was given in the same troughs individually, and the remainder was weighed at $8 \mathrm{AM}$ on the day after. Approximately $45 \%$ of TDN requirement (calculated from live weight and milk production just before the experiment) was given as a concentrate (CP $14.7 \%$, C. Fiber $6.5 \%$ on DM basis). The daily amount of

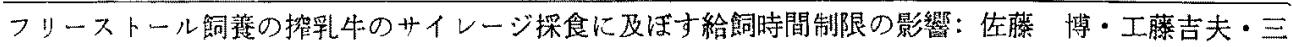
息斩夫（北海道装業試験場 札㹸市 061-01） 
concentrate was given in 4 meals at $6 \mathrm{hr}$ intervals using an electronic feeder (Feed station).

Each experimental period was 12 days. The intakes of silage, hay and concentrate were measured everyday, and the intakes from the last 5 days were analyzed statistically by least significant difference.

\section{Results and Discussion}

Mean milk production was comparatively low ( $16 \mathrm{~kg}$ daily) in consequence of the late lactational stage in many cows used. There was little refusal of the concentrate allowed. Mean daily intakes of the concentrate and hay in each treatment were 6.16.2 and $3.2-3.7 \mathrm{~kg}(\mathrm{DM})$, respectively. Daily DM intake of $9.2-9.9 \mathrm{~kg}$ from the concentrate and hay represents $1.45-1.6 \%$ of live weight.

Silage intake at each time access is shown in Fig. 1. Mean DM intake from the silage was $6.5,8.6,10.4$ and $11.8 \mathrm{~kg}$ daily for $2,5,10 \mathrm{hr}$ and free access to the silage. The intake was reduced to 56,74 and $89 \%$ of the free access group's by time restriction to 2,5 and $10 \mathrm{hr}$, respectively. The intake of the 2 and $5 \mathrm{hr}$ access group was significantly lower than that of the free access group, but that for $10 \mathrm{hr}$ was not significantly different. On an average, the cows took up $23.1 \mathrm{~kg}$ (fresh) of the silage in $2 \mathrm{hr}$ of access period. This indicates that the cow's eating rate was more than $190 \mathrm{~g}$ (fresh) $/ \mathrm{min}$.

Concerning maximum DM intake, most figures were less than $20 \mathrm{~kg}$ daily ${ }^{1,2)}$. In the present cows housed in a free stall barn, daily DM intake from all the diets was 16. 4, 18.2, 20.0 and $21.0 \mathrm{~kg}$ for $2,5,10 \mathrm{hr}$ and free access treatment, respectively. These figures were equivalent to $2.6,3.0,3.2$ and $3.3 \%$ of their live weight.

It has been suggested that $6 \mathrm{hr}$ access is probably an adequate period for stall fed

Silage intake (DM)

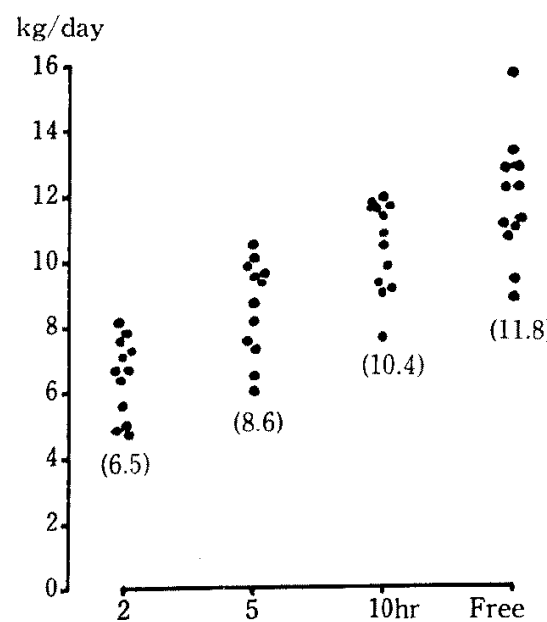

$\%$ Decline of silage intake

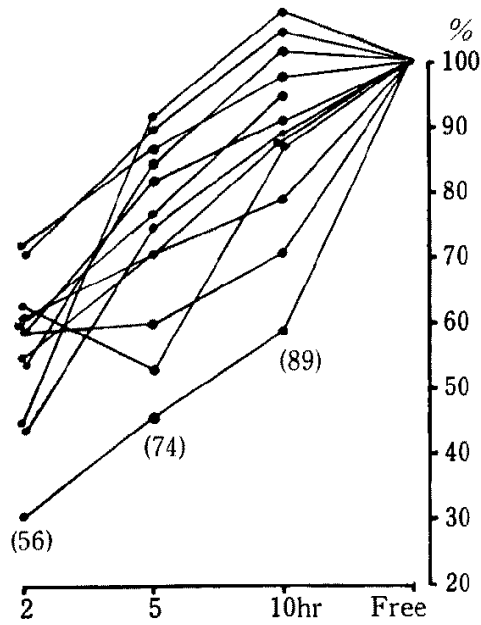

Fig. 1. Decrease in silage intake by restriction of time access to silage. Figures in parenthesis are mean of 12 cows. 
cows to maximize their silage intake ${ }^{1)}$. FrEer and CAMPLing ${ }^{3)}$ observed for hay feeding that an increased time access from 5 to $24 \mathrm{hr}$ resulted in only a $20 \%$ higher intake.

Similarly to the present results, however, a considerable decrease of silage intake was reported by HARB and CAMPLING ${ }^{4}$. They observed a grass silage intake of 8.94 and $12.22 \mathrm{~kg}$ (DM) daily for 5 and $22 \mathrm{hr}$ access in group housed dairy cows receiving $1 \mathrm{~kg}$ concentrate everyday. Forage intake is influenced negatively by concentrate feeding ${ }^{2)}$. In very limited access time, however, it is reasonable that forage intake may be more influenced by eating behaviour (e.g., eating rate, competition) rather than by concentrate given. Present results indicate that shortening of access time to 2 or $5 \mathrm{hr}$ daily is inadequate for enough intake of silage.

\section{References}

1) Bines, J.A., in Feeding Strategy for the High Yielding Dairy Cow. (Broster, W. H. and H. SWAn eds). 23-48, Granada, London and NY. 1979.

2) Journet, M. and B. Remond, Livst. Prod. Sci., 3: 129-146. 1976.

3) Frezr, M. and R. C. Campling, Br. J. Nutr., 17: 79-88. 1963.

4) Harb, M. Y. and R. C. Campling, Grass Forage Sci., 38: 115-119. 1983. 